nari smiju predstavljati probleme. Ipak, DOI: $10.5613 /$ rzs.46.3.6 alternativni bi mediji trebali obratiti pozornost na njegove ideje. Jedan od rijetkih pozitivnih efekata smanjivanja povjerenja u državne institucije jest poprilično otvoreno i živo područje borbe tumačenja društvene stvarnosti, gdje se, između zastarjelih srednjostrujaških formula i zabavnih teorija zavjere, alternativni mediji imaju priliku stalno iznova dokazivati najsuvislijima. Iako im je prioritet borba za vlastitu strukturnu održivost, presudno je da održivost postignu inzistiranjem na kvaliteti svojih tumačenja, u čemu im je Stones partner kako autorskim entuzijazmom, tako i analitičkim uvidima.

Osim medijskih radnika, drugi profil publike za Why Current Affairs Needs Social Theory jesu oni pripadnici akademske zajednice (mahom sociolozi) koji vjeruju da je društvena teorija najbolji rezervoar tumačenja društvenog svijeta. Dapače, relacijska sociologija u tome je izdašna polazišna točka i lako ju je dalje nadopunjavati pojedinačnim ingenioznim doprinosima iz njezinih više od sto godina tradicije. Stonesov je projekt blizak svima koji to obilje žele približiti ostatku svijeta.

Leonard Jurić Zagreb

\section{Proslava 40. godišnjice Odjela za sociologiju Sveučilišta u Zadru}

Zadar, 20. travnja 2016.

Odjel za sociologiju Sveučilišta u Zadru 20. travnja 2016. godine obilježio je 40. godišnjicu svojega znanstvenog i nastavnog djelovanja svečanom proslavom i prigodnom akademskom raspravom. Toj značajnoj obljetnici prisustvovali su brojni uzvanici i gosti koji s Odjelom surađuju u okvirima svojega akademskog i stručnog djelovanja. Iz programa proslave i izlaganja bilo je primjetno da su se razvojni fokus $i$ primarno usmjerenje Odjela mijenjali tijekom godina u skladu s aktualnim društvenim promjenama kao i potrebama struke da se istraživački i kritički osvrne na njih.

Govori uzvanika, uzvanica i domaćina proveli su nazočne kroz zaokruženu priču djelovanja Odjela za sociologiju od vremena osnivanja 1976. godine, kao Odsjeka pri tadašnjem Filozofskom fakultetu u Zadru, pa sve do danas. Svojim su prisjećanjima na rad i suradnju s nekima od brojnih sociologa i sociologinja poput Ivice Maštruka, Nikole Skledara, Đure Šušnjića, Mislava Kukoča, Darka Polšeka, Erme Ivoš Nikšić, Anči Leburić i Inge Tomić-Koludrović, koji su se tijekom tih četrdeset godina, između ostaloga i u okvirima Odjela, profilirali unutar hrvatske sociologije, predočili prisutnima ustrajnost u izgradnji kvalitetnih 
znanstvenih, nastavnih i stručnih temelja na kojima se Odjel i danas nastavlja razvijati. Tako je u svojem govoru pročelnik Odjela prof. dr. sc. Saša Božić prikazao znanstveni doprinos Odjela, koji je prvobitno dulji niz godina bio usredotočen na etabliranje sociologije religije u Hrvatskoj, da bi se kasnije tematski preusmjerio najprije na kulturne politike, a potom i intenzivna istraživanja mladih, žena i životnih stilova. U novije je vrijeme svojim nastavnim programom usmjeren na oblikovanje akademskih građana koji će »znati djelovati u društvu i za društvo« poticanjem kreativnosti i razvoja sociološkog zanata. Prof. dr. sc. S. Božić ukazao je na to da Odjel ujedno teži i otvaranju prema lokalnoj zajednici organizacijom predavanja i okruglih stolova u okviru višegodišnjeg projekta Javna sociologije te međunarodnim suradnjama kroz mobilnost studenata i nastavnika, združene studijske programe na diplomskoj i poslijediplomskoj razini, kao i održavanje znanstvene mreže Social Science and the Sea (SSASEA).

Prof. dr. sc. Josip Faričić, prorektor za strategiju razvoja i izdavaštvo, u ime rektorice prof. dr. sc. Dijane Vican i uprave Sveučilišta u Zadru također je istaknuo da iskorak Odjela prema lokalnom i međunarodnom kontekstu znatno pridonosi prepoznatljivosti samog Sveučilišta u Zadru. Predsjednica Hrvatskoga sociološkog društva izv. prof. dr. sc. Jasminka Lažnjak pohvalila je osobito zamjetnu znanstvenu aktivnost Odjela u djelokrugu zadarske podružnice HSD-a, kao i njegovo usmjerenje na promociju $\mathrm{i}$ isticanje relevantnosti same struke $\mathrm{u}$ društvu. Prema riječima mr. sc. Ratka Čorića, bivšeg studenta Odjela i najdulje zaposlenog djelatnika na Odjelu, dvije su ključne prekretnice u novijoj povijesti bitno utjecale na oblikovanje i usmjerenje njegova današnjeg rada. Prva je uspješno prilagođavanje studijskih programa bolonjskom procesu uz vodstvo tadašnje pročelnice prof. dr. sc. I. Tomić-Koludrović, a druga zapošljavanje nekolicine asistenata i već afirmiranih sociologa $\mathrm{u}$ trenutku u kojem je Odjel imao samo troje zaposlenih. Studij sociologije u Zadru iz perspektive studenata i studentica sociologije opisao je njihov predstavnik Pavao Parunov kao proces postupnog prelijevanja promišljanja društvenih pitanja iz okvira nastave u studentsku svakodnevicu. Društveni angažman studenata i prilike za ostvarenjem znanstvenog doprinosa obilježeni su nadmetanjem između osjećaja osnaženosti i obeshrabrenosti, koji proizlaze iz kolebljivih mogućnosti neposrednog djelovanja studenata $\mathrm{i}$ studentica unutar vlastite svakodnevice.

U ime Odjela pročelnik prof. dr. sc. S. Božić izrazio je zahvalnost ponajprije osnivaču tadašnjeg Odsjeka za sociologiju prof. em. dr. sc. Esadu Ćimiću, a potom i bivšim pročelnicama prof. dr. sc. Ermi Ivoš Nikšić, prof. dr. sc. Anči Leburić i prof. dr. sc. Ingi Tomić-Koludrović. S obzirom na to da zbog spriječenosti nije mogao sudjelovati u proslavi, prof. em. dr. sc. E. Ćimić je putem snimljenoga telefonskog obraćanja objasnio da se od osnutka zadarskog studija sociologije osobita 
pozornost nastojala posvetiti ujednačenom ovladavanju teorijskim i empirijskim znanjima. Iscrpno proučavanje društvene problematike uključuje trajno promišljanje tog odnosa što je u svojoj poruci posebno naglasio novim generacijama studenata i studentica. Prof. dr. sc. A. Leburić se, primajući zahvalnicu, prisjetila teškoća rada u poslijeratnim godinama, koje su nadvladavane studentskom znatiželjom, nastavničkom predanošću te obostranim poštovanjem prema radu i struci. Nadovezujući se na prethodne govore, prof. dr. sc. I. TomićKoludrović dodatno je naglasila zasluge svojih kolega i kolegica koji su dolaskom u Zadar, uz suradnju i iznimnu potporu uprave i stručnih službi Sveučilišta, omogućili proces revitalizacije Odjela od 2005. godine, zbog čega je Odjel bio u stanju ostaviti »važan pečat [u] suvremenoj hrvatskoj sociologiji«.

U akademskom programu proslave, koji je osmišljen i organiziran u suradnji sa zadarskom podružnicom Hrvatskoga sociološkog društva, tematizirani su ključni izazovi i uloga sociologije u Hrvatskoj. Predavači/ce i sudionici/e okruglog stola pristupili su višeslojnom pozicioniranju sociologije u Hrvatskoj, a povrh svega, razmatranju odnosa ukupnoga sociološkog djelovanja i društva kojemu se obraća i unutar kojega djeluje. Rasprave su zbog toga obuhvatile mnogobrojna i raznovrsna pitanja, počevši od relevantnosti struke u okvirima srednjoškolske nastave, financiranja znanosti i s time povezane međuigre znanstvenog objavljivanja i produkcije kontekstualno relevantnoga društvenog znanja, do pitanja unutardisciplinarnoga metodologijskog i teorijskog uraznoličenja, kao i značaja dijaloga s javnosti kroz tumačenja društvenih pojava.

U uvodnom izlaganju pod nazivom »Sociologija i zdravi razum: ezoterija, prosvjećivanje, marketizacija (predrasuda)«, prof. dr. sc. Vjeran Katunarić nastojao je smjestiti »pluralistički karakter« sociološkog razumijevanja društvenih pojava u složeni odnos sa zdravorazumskim iskustvom te time ukazati na bitne popratne uloge sociologa/inja $\mathrm{u}$ nastavi i izvan nje. U prvome se modelu ovoga odnosa, koji je nazvao ezoteričnim, ponajviše ističe prosvjetiteljska uloga nastavnika/ce sociologije, čija je zadaća tumačenje ponekad jezično nerazumljivih ili formalnih postavki teorija. Drugi model, koji predavač određuje kao demokratsko prosvjetiteljstvo, karakterizira izgradnja dijaloga s javnošću. Nasuprot tim modelima, treći je kvazisociološki, antiprosvjetiteljski model zbog njegove tendencije prema marketizaciji predrasuda i marketizaciji znanosti. Naposljetku je prof. dr. sc. V. Katunarić upozorio da uvjete za prosvjećivanje nije preporučljivo čekati nego da ih treba kontinuirano graditi, pogotovo $\mathrm{u}$ antiintelektualnom kontekstu "pseudodemokratskih režima« $\mathrm{i}$ »evanđelja neoliberalizma« s kojima se i sociologija suočava u znanstvenom i strukovnom djelovanju. Referirajući se ponajprije na važnost spomenutoga modela demokratskoga prosvjetiteljstva, u nastavku je, u svojstvu respondentice, izv. prof. dr. sc. Jadranka Čačić Kumpes skrenula pozornost na status nastav- 
nog predmeta sociologije u hrvatskome obrazovnom sustavu. Opomenula je na zanemarenost sociologije unutar srednjoškolskog obrazovanja te jasnu neusklađenost između zadaća nastave sociologije i uvjeta za njezino izvođenje. U tome je smislu skrenula pozornost na činjenicu da srednjoškolski nastavnici/e sociologije očekuju stručnu potporu znanstvenika/ca, a smatraju je nedostatnom.

Akademski dio proslave nastavio se okruglim stolom pod nazivom »Sociologija u Hrvatskoj danas: između profesionalne i javne«, koji je otvorio i moderirao mr. sc. Mirko Petrić, a u kojem su sudjelovali/e izv. prof. dr. sc. Jasminka Lažnjak, dr. sc. Jadranka Švarc, prof. dr. sc. Siniša Zrinščak i prof. dr. sc. Inga Tomić-Koludrović. U uvodnom dijelu mr. sc. M. Petrić postavio je tematsku okosnicu stola i pozvao sudionike/ce na razgovor o pozicioniranju sociološkog djelovanja u Hrvatskoj u kontekstu podjele sociologije na javnu, profesionalnu, kritičku i javnopolitičku (policy) sociologiju nekadašnjeg predsjednika Američkoga sociološkog udruženja Michaela Burawoyja. Izv. prof. dr sc. J. Lažnjak i dr. sc. J. Švarc predstavile su podatke koji ukazuju na opći trend sve nižih financijskih ulaganja u znanost od 2004. godine te se osvrnule na (ne)mogućnost ispunjenja istovremenih zahtjeva za znanstvenom izvrsnošću. U prikazu rezultata bibliometrijske analize naglasile su, međutim, dobru rangiranost Sveučilišta u Zadru i Odjela za sociologiju po produkciji znanstvenih publikacija. Prof. dr. sc.
S. Zrinščak istaknuo je nužnost daljnje profesionalizacije hrvatske sociologije, $\mathrm{u}$ čemu je pozornost publike osobito usmjerio na problem podizanja kvalitete znanstvenoga izdavaštva i potrebu standardizacije recenzijskoga postupka. Prof. dr. sc. I. Tomić-Koludrović u svojem je izlaganju posebno ukazala na to da rad na unapređenju discipline, znanstvene produkcije i općenitoj akumulaciji spoznaja o hrvatskom društvu predstavljaju bitne spone za uzajamni razvoj kako profesionalne, tako i javne sociologije.

Osim propitivanja uloge sociologije i njezinih doprinosa za razvoj javne sfere u Hrvatskoj, prisutni su se svojim komentarima, iskustvima i pitanjima osvrnuli na izdavaštvo i financiranje, nesigurnost položaja znanstvenih novaka i novakinja te kriterije znanstvenih napredovanja. Pritom su jasno artikulirani i naglašeni dosadašnji napori akademske zajednice prema podizanju relevantnosti sociološke struke u širim društvenim okvirima, no i nužnost daljnjih nastojanja učvršćivanja znanstvenog i stručnog temelja razvoja Odjela. Relevantnost teme akademskog dijela proslave, kao i potreba za daljnjim nastavkom razgovora i refleksivnosti, očituje se u samom produljenju programa i njegovim zaključenjem gotovo sat vremena nakon predviđenog završetka.

Nakon te plodonosne proslave obljetnice na Odjelu za sociologiju u narednim se danima, od 21. do 23 . travnja 2016. godine, održavala međunarodna znanstvena konferencija »Religija i ne-religija u suvremenim društvi- 
ma«, koju je organiziralo Međunarodno ju Sveučilišta u Zadru, kao i značajan udruženje sociologije religije Srednje i interes za temu akademske rasprave, Istočne Europe (ISORECEA), a koja se potvrdili su njegovu važnost za dosaodvijala pod pokroviteljstvom Europ- dašnji, ali i budući razvoj hrvatske soskoga sociološkog društva i Hrvatskoga ciologije.

sociološkog društva. Velika posjećenost

Marija Šarić

obljetničkog skupa Odjela za sociologi-

Zadar 